\title{
RADICAL ISLAM - INFECTIOUS FEAR AND CULTURAL IMMUNOLOGICAL REACTIONS
}

ABSTRACT. Jacek Zydorowicz, Radical islam - infectious fear and cultural immunological reactions, edited by Z. Drozdowicz and S. Sztajer, "CZłowiek i Społeczeństwo” vol. XLI, Poznań 2016, pp. 125-146, Adam Mickiewicz University Press. ISSN 0239-3271.

Globalization is often treated as a catch-all category, which is a universal frame of reference in the discourse of the humanities, social studies, but also economic, political, and many other fields. Depending on the perspective, some evaluate it very positively, recognizing the benefits; others, on the contrary, point out the threats, and undesirable side effects. Meanwhile, in the reflection on religions, globalization launches a range of fears and concerns (more or less openly articulated). The unquestionable ally of this phenomenon is the modern media, whose tabloid nature is more emotional than rational. Religious conflicts are often overexposed, which, in turn, accelerates tension and social phobias. Both the mainstream media and the propaganda of the Islamic State are trying to imitate the rhetoric known from the movies at the cinema. As a result, by such pop-culture cliches the Western world interprets the influx of Syrian refugees as a cultural invasion (or a religious crusade). This creates a situation of a widespread infection of fear, which triggers the cultural immune responses: rationalizations, denial, conspiracy theories, humour and aggression. Visual artists propose quite a different repertoire of resistance tactics.

Jacek Zydorowicz, Adam Mickiewicz University in Poznań, Institute of Cultural Studies, ul. Szamarzewskiego 89C, 60-568 Poznań, Poland, e-mail: jazy@amu.edu.pl

The word "Islam" has ceased to sound neutral since September 11, 2001. It no longer merely denotes one of the universalistic religions, as it has become more of a multi-faceted discourse infused with emotional tension. Paradoxically, this presents us with both complexity and reductionism at the same time. On the one hand, Islam treated as a cultural discourse is a conundrum of phenomena, a point of intersection of various vectors such as religion, 
globalisation, the economy, politics, and networked information; on the other hand, politically and in terms of the media it is reduced to terrorism running on fundamentalist fuel. In consequence, the collective consciousness of western societies has initially identified Islam with Al-Qaeda, later with the Taliban, and finally with the so-called Islamic State ${ }^{1}$ (which entity has been referred to by Charles Krauthammer ${ }^{2}$ as “Al-Qaeda on steroids"). The common identification of Islam with terrorism has induced social tensions, in whose background we can find stronger or weaker articulations of phobias, fears and anxieties. While in Al-Qaeda's case they were focused on representations (or perhaps icons) of Osama bin Laden or the falling WTC towers, ISIS is in the business of distributing fear of a different nature: it has utilised a spatial rhetoric based on the projected map of a new caliphate, which is supposed to soon encompass the Middle East, Northern Africa and a large part of Europe. In practice, our fears do not so much concern Islam itself as the extremist ideology instrumentalising this religion, which also includes its political and social consequences.

\section{Globalisation and terrorism}

Globalisation is oftentimes treated as a do-it-all category, i.e., a highly universal frame of reference in various discourses - the social, economic, political, that of the humanities, as well as many others. Depending on the perspective, some value it highly positively emphasising gains, while others, quite to the contrary, point to threats and unwanted side-effects. When it comes to the followers of various religions, the notion of globalisation is typically associated with a range of misgivings, usually generated by the fear of losing the integrity and identity of the local religious formation (fear of being dominated by some other religion or of secularisation). History teaches us that a natural effect of such a state of affairs comes in the form of resistance, often of the armed sort. This is especially true of the globalisation processes of the imperial model - one could for instance refer

${ }^{1}$ Islamic State - alternately known as: Islamic State of Iraq and the Levant (ISIL), Islamic State of Iraq and Syria or Islamic State of Iraq and al-Sham (ISIS), Daesh (acronym of the Arabic name, which is nevertheless not accepted by the ISIS fighters, as daesh also means "downtrodden," "crushed") - a jihadi quasi-state formed on the foundations of the war-time chaos in Iraq and Syria. In 2014, this Salafist terrorist organisation proclaimed itself a caliphate.

${ }^{2}$ Charles Krauthammer - an American conservative pundit, publishing for instance in the "Washington Post." 
to the terrorist tactics of the Zealots against the Roman occupation. Is it, nevertheless, warranted to follow Paul Wilkinson in stating the thesis that the contemporary terrorism constitutes a reaction to globalisation, ${ }^{3}$ or are we only dealing with a series of correlations (sometimes epiphenomenal)? ${ }^{4}$ From the methodological point of view, the task seems to constitute a thorny enterprise, due to the lack of any unequivocal definitions of both terrorism and globalisation. Paradoxically, there is a clear over-abundance of these definitions, which leads to a simultaneous ease of the political-rhetorical instrumentalisation and the difficulty of intersubjective understanding. Creating an ad hoc fusion of dozens of different definitions, I refer to terrorism as the violence-based tactics aimed at creating fear, which leads to gaining concessions of a political nature (in a broad sense). ${ }^{5}$ If we were to provide a similar treatment to the other broad term, then globalisation could refer to the multi-faceted complex of phenomena, which in the economic sense comprise the deepening, hastening and intensifying of international and supranational networks of relationships, of the exchange of goods and technologies; while in the political sense, as well as in the social and cultural, it entails an easier circulation of information, ideas and migrations of people, etc. This may sometimes lead to cultural homogenisation through encounters, at other times to the sharpening of differences and increased inequalities (social and economic) - and consequently - to conflict.

Looking into the potential correlations of terrorism and globalisation during the attempts at creating the new world-order after the Second World

${ }^{3}$ P. Wilkinson, Why Modern Terrorism? Differentiating Types and Distinguishing Ideological Motivations, in Ch.W. Kegley, Jr. (ed.), The New Global Terrorism: Characteristics, Causes, Controls, Prentice Hall, Upper Saddle River, NJ 2003, p. 124.

${ }^{4}$ For a detailed investigation of the topic - cf. Brenda J. Lutz, James M. Lutz, Globalisation and Terrorism in the Middle East, in Perspectives on terrorism, vol. 9, issue 5, pp. 27-46.

${ }^{5}$ At the same time, it seems important to note that this definition is obviously coined from an external perspective, as precious few groups would use the notion of "terrorism" to call their own tactics. Members of such organizations prefer such terms as fighter, revolutionary or partisan. Therefore, it remains impossible to avoid situations where the term "terrorist" is carelessly used in the political discourse to stigmatize the opponent. Such emotional language is conducive to abuse and makes the term even more hazy - one can use the example of the contemporary conflict in Ukraine. After the events on the Kyiv Maidan, politicians would use the notion of an "anti-terrorist" operation instead of simply calling it war. This sounded emotional and sharp, and thus was prone to reproduction on the part of the western media. It took time for the "Donbas terrorists" to be rebranded as separatists. Therefore, I would like to emphasize that my use of the term terrorism is non-evaluative, in contradistinction to the currently typical and politically correct usage. 
War, we are pushed towards the post-colonial discourse. This is especially visible when it comes to the Middle East and Northern Africa, where state boundaries were delimited with lines that cared little for ethnic, religious or cultural factors. Following the suggestions of David Rapaport ${ }^{6}$ it is possible to distinguish four waves of terrorism:

- the anarchist wave (inspired by The Revolutionary Catechism by Sergey Nechayev, and the writings of Michail Bakunin);

- the nationalist wave (anticolonial movements, insurgent terrorism of the Algerians, Palestinians, the republicans of Northern Ireland, the Basque ETA, Zionists, etc.);

- the anarchist-left wave (stemming from the disenchantment with the 1960s counterculture, e.g., the German Rote Armee Fraktion, Italian Brigate Rosse or the American Formation Weather Underground, etc.);

- the wave of religious terrorism (on the rise from the 1990s when, for instance, the nationalist and leftist Organisation for the Liberation of Palestine was becoming superseded by the religious Hamas; and resulting from the Soviet intervention in Afghanistan, the Al-Qaeda came to be formed; and the Aum Shinrikyō dispersed sarin gas in the Tokyo underground in 1995, in which year Timothy McVeigh committed an attack in Oklahoma City; while since 2002 Boko Haram started operating intensively in Nigeria).

One should obviously take into consideration the intermingling and interference of these different waves: in Northern Ireland there was a successful comeback of the Marxist-leaning INLA (Irish National Liberation Army); the religious factor has often marched hand-in-hand with the national-insurgent movement (Irish Republican Army), and both the IRA and the German anarcho-leftist formations had alliances with the Palestinians of El-Fatah. Contrary to common opinions, international terrorism is not a phenomenon characteristic only of the last decade.

It also seems important to observe that the programmatically anti-globalist (or alter-globalist) social movements - in operation since the 1990s - have not yet produced any terrorist acts in spite of their radicalism and scale. Therefore, in my view, it is not globalisation as such that generates terrorism, so much as some of its imperial political and economic aspects (such as the US military interventions in the Middle East). At some further level there are also cultural factors - when some local identities breed fundamentalisms through the anxieties generated by foreign ideas, which are perceived as threatening the integrity of their own symbolic order. Ac-

${ }^{6}$ D.C. Rapaport, The Four Waves of Rebel Terror and September 11th, in Ch.W. Kegley, Jr. (ed.), The New Global Terrorism..., pp. 36-52. 
cording to Anthony Giddens, this would amount to the conflict along the cosmopolitanism - fundamentalism axis. ${ }^{7}$

The fact seems nevertheless indisputable that the newest global technologies of communication create tools making it easier to recruit and organise jihadi groups and cells, and - what is even more important - that the Internet provides powerful publicity for making threats and a two-directional mode of communication. Even in the first decade of the new millennium, Al-Qaeda communicated with the world using video-tapes, which were posted to the Qatari-based Al-Jazeera TV-station, which in turn would serve as the re-broadcast source for global information agencies. The networking of terrorist propaganda ran in parallel to the dynamic development of the world-wide web infrastructure as well as of the cellular-phone access in Muslim countries (for the diaspora dwelling in Western countries these came obviously much earlier). ${ }^{8}$ Still, this does not prove the validity of the positions linking globalisation with contemporary terrorism. One cannot blame the tools of communication for the content of the messages and their consequences - the Internet does, for instance, facilitate terrorist activities just as much as it helps charitable initiatives.

\section{Fear infections}

The persuasive functions of fear are relatively well recognised, and have been well documented in Jean Delumeau's book Strach w kulturze Zachodu $X I V-X V I I I w^{9}{ }^{9}$ The sources of these kinds of fear came in the form of the plague, starvation, Satan or his agents (i.e., witches, heretics, Jews, as well as Turks during the ascendancy of the Ottoman Empire). The sum of these fears was a dominant force, and the Church was attempting to fight them through cataloguing and picking enemies. In the context of contemporary problems, the observations of Delumeau are far from outdated. At this point, it would also seem to be in order to make a distinction between fear and anxiety. While the first of these emotions is triggered under conditions of

${ }^{7}$ A. Giddens, Runaway world. How globalization is reshaping our lives, Taylor \& Francis, London 2003.

${ }^{8}$ Further reading on this topic: C. Bocksette, After Bin Laden: Jihadist Terrorist Use of Strategic Communication to Enlarge Community of Believers, and P.K. Foster, Terrorist Innovation: Homegrown Terrorism and the Internet, in J.J. Le Beau (ed.), The Dangerous Landscape. International Perspectives on Twenty-First Century Terrorism; Transnational Challenge, International Responses, Procon Ltd, 2013.

9 J. Delumeau, Strach w kulturze Zachodu XIV-XVIII w., Warszawa 1986. 
real danger (e.g., a report about a bomb when we are taking part in a mass event), anxiety is to a large extent the effect of anticipation, often irrational (e.g., millennial or xenophobic anxieties ${ }^{10}$ ). Under such conditions, on the one hand, we can nowadays observe anxious masses, and on the other hand, there are the skilled managers of supra-cultural emotions (fears, phobias and anxieties), who perform a transfer of uncertainty over an increasingly global scale.

In recent years, Al-Qaeda's place on the international arena of fear was assumed by a new dynamic actor, i.e., the aforementioned Islamic State. In short, it constitutes a Sunni organisation fighting at this point against the Shia (mostly against Alawi), the Kurds, the Yazidis, Christians, the forces of Bashar Al-Assad, the Free Syrian Army (oppositional with respect to Assad forces), and the whole western world. Paradoxically, this formation came into being thanks to the American Camp Bucca ${ }^{11}$ prison in Iraq, where former operatives of Saddam Hussein's intelligence service had a chance to meet. An even greater paradox comes from the fact that the close governing circle of the organisation was composed of the ex-functionaries of the left-wing Baath party (e.g., Izzat Ibrahim al-Douri, Abu Ayman al-Iraqi, Abu Muslim al-Turkmani). Territorial expansion was facilitated on the one hand by the ability to take over the arsenal which the Iraqi army inherited from the US, and, on the other, by recruitment successes and the franchising effect (the ISIS flag was willingly appropriated by smaller jihadi cells from Africa, Europe and other parts of the world).

\section{Content of ISIS threats?}

Having taken on board the lessons of the Bush doctrine of shock and awe, as well as dwelling on local traditions, ISIS goes much further than Al-Qaeda

${ }^{10}$ A disputable case is presented by the classification of the current Polish attitude with respect to Syrian refugees as either anxiety or fear. Although Pope Francis makes appeals for Europe to assume a Christian attitude of mercy and solidarity, yet, on the one hand, this tends to rationalize threats (security experts speak of possible "wolves in sheep's clothing,” Jarosław Kaczyński warns of "parasites threatening our organisms,” the media timidly report on the cases of European women being assaulted by immigrants), and on the other hand, the Poles have not yet had any problems with Muslims living in Poland (discounting occasional discussions around the ritual slaughter of animals), and Poland itself is not an attractive destination point for the refugees.

11 The name of the camp was supposed to commemorate Ronald Bucca, one of the firefighters who died in the rubble of the WTC in 2001. 
or the Taliban have gone. A new and much enlarged repertoire of terrorist acts and visual rhetorical devices is utilised. The Jihadis employ a variety of attention-grabbing scenarios as elements of their psychological war.

Executions - which typically do not relate to any demands (e.g., to free comrades in return for the freedom of the hostage), which was typical of the "traditional" terrorism. Nowadays, the spectacular, elaborately conceived execution is supposed to serve as the message. Of common usage are: the beheadings of enemies and hostages, burning them alive, blowing people up, throwing them down from rooftops (most frequently for homosexuality), cutting off thieves' hands or crucifixions. At every occasion, these are firmly documented - sometimes we can witness killing scenes arranged in crowded public spaces (filmed from above with the help of drones), and some executions are especially arranged so as to serve the needs of cinematographic productions such as A Message Signed with Blood to the Nation of the Cross. In order to produce such a film, in the beginning of 2015, 21 Coptic Christians were executed on the Libyan shore. Unlike hitherto, this was not an amateur-like video of the execution; in fact, every shot was meticulously worked out. Scenes, shots and camera motions exhibited a perfect mastery of the grammar of film-making. It seems worth mentioning that the most drastic scenes in these productions are not shown in the mainstream Western media, yet they can easily be found on websites of, for instance, the Christian radicals (e.g., catholic.org). In principle, this may be meant to serve as a means of anti-Muslim mobilisation; however, it seems to serve as yet another amplifier of the jihadi message. The Polish media had also raised this issue, pointing to the controversial conduct of a Polish religion teacher who showed the film presenting the execution of the Coptic Christians, as it espoused a non-positive affirmation.

Resort terrorism - on March $18^{\text {th }}$, 2015, Jihadis performed an abortive attack on the Parliament in Tunis, after whose failure the tourists in the nearby Bardo Museum became a secondary target. 24 people of different nationalities died (mostly Europeans). In June of the same year, a 23-year-old terrorist, Sajf ad-Din ar-Rizki, shot 39 people in a resort-complex in Tunisian Susa. The media were flooded with oxymoronic pictures of a serene beach and blood-stained bodies covered with towels. In effect, a state of emergency was imposed strengthening security measures, yet many travel agencies cancelled their reservations, which had a dire impact on the country's economy. Similarly, in Egypt, local ISIS cells declared their responsibility for downing an Airbus A321 with 224 people on-board (mostly Russians), which was flying from Sharm el-Sheikh to Saint Petersburg on October 31st, 2016. 
Destruction of Antiquities - an international shockwave arose after actions which the Western media referred to as cultural vandalism. Ancient civilizational heritage was targeted in the cities of Nimrud (Iraq) and Palmyra (Syria). Archaeological stations and ruins were spectacularly blown up and bulldozed, as some of the monuments were destroyed in an iconoclastic zeal, just as others were - more pragmatically - peddled to collectors. The very old Christian temples were treated with equal barbarity - for instance, in the case of the Saint Elian monastery in Homs, the sarcophagus with its bodily remains was destroyed. ${ }^{12}$

Training camps for children - the ruins of Palmyra also served as the scenery for another spectacular torment of the soldiers of the Assad army. The difference came in the fact that the execution was perpetrated by teenage youth shooting pistols. This was not an isolated event, as clips were soon uploaded online depicting the killing of a Palestinian, and then of two Russians. In this case, the issue is not only with the ethical dissonance within the shock doctrine within the scenarios of the ISIS propagandists. Boiling it down to statements about brainwashed youth does not also explain much. These are not only terrorists' children, but for the most part they are war orphans without alternatives. Of course, this is one way of producing loyal fighters, but apart from that, the early initiation into killing constitutes an emancipatory "bonus" as well as a boost for the social rank among peers.

Rapes, sex-slavery of the unfaithful - human rights organisations distribute multiple personal testimonies of women who managed to escape ISIS captivity. Yazidis, Shia, Kurds and Christians can all relate their tragic experiences “I've been raped 30 times and it's not even lunchtime. I can't go to the toilet. Please bomb us!"13 In order to avoid the stigma of disgrace for their families, most of the stories being told involve heroines who somehow managed to "evade" the rapes.

Burning alcohol and tobacco at the stake - these spectacles are meant rather for the internal addressees, and these actions are meant to promote moral patterns in accordance with the qur'anic guidance with respect to stimulants. With time, some of the restrictions on smoking were lifted as many of the European recruits had a difficulty quitting this addiction. The

${ }_{12}$ N. Gutteridge, The World Heritage sites ISIS could blow up in campaign of cultural vandalism, http://www.express.co.uk/news/world/602428/Islamic-State-ISIS-World-Heritage-sites-pyramids-palmyra [access:12.11.2015].

${ }^{13}$ Text of a flyer for the campaign \#SaveYazidis. 


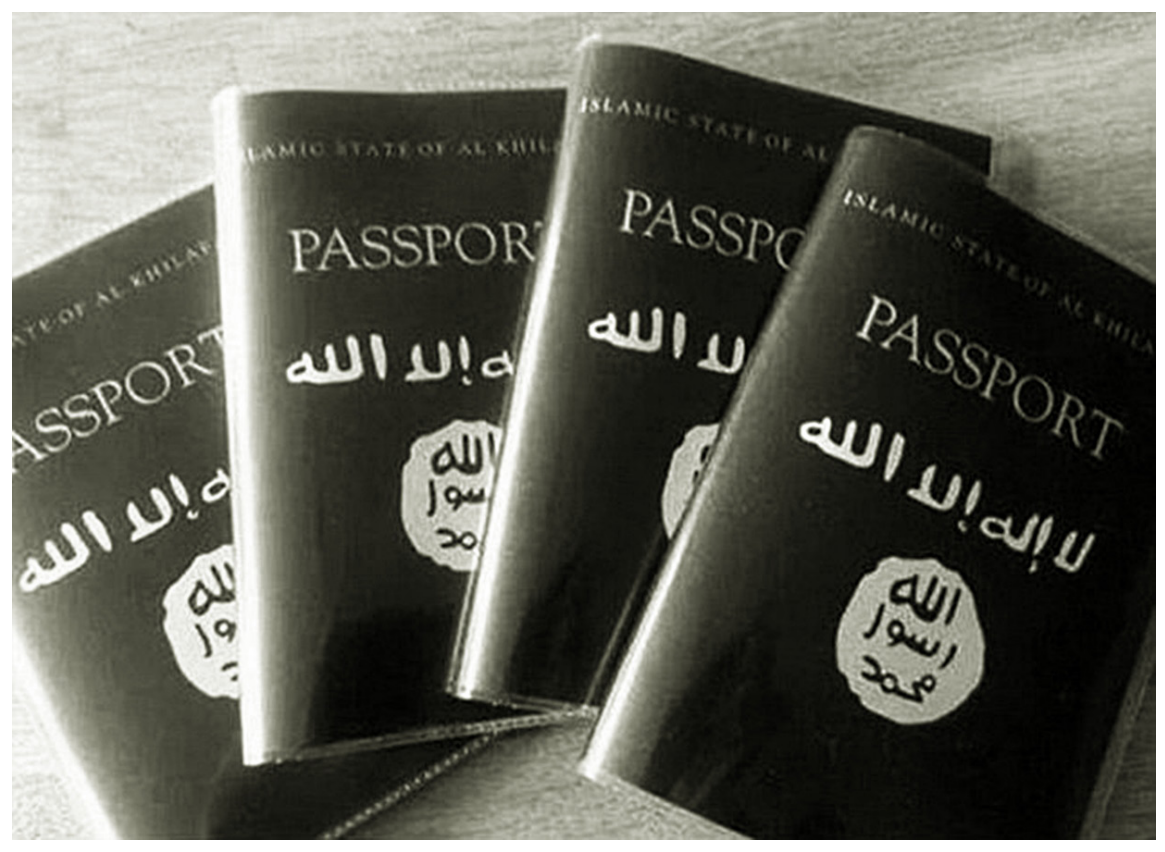

Source: http://www.dailymail.co.uk/news/article-2722637/Anything-declare-ISISlaunches-passport-holders-international-terrorist.html [access: 12.11.2015].

side-effect of these measures has been a five-fold increase in the price of alcohol in Iraq and Syria. ${ }^{14}$

Dynamic expansion and recruitment success - these seem threatening both locally and from the point of view of Western societies and politicians. The military success of ISIS was facilitated by the take-over of Iraqi army arsenals accompanied by the magnitude of financial gains from controlling oil-fields as well as from ransoms, which were combined with the brevity of subsequent conquests (special efficacy in this respect was demonstrated by units formed of Chechens under the command of Tarkhan Batirashvili, whose name assumed for the caliphate was Abu Omar al-Shishani). This significantly affected the image of terrorism. Previous actions of Al-Queada accustomed us to attacks of dispersed units hiding in caves, and engaging in surprise attacks. In contrast, ISIS projects an image of open battle, exhibiting

${ }^{14}$ New images show ISIS torching alcohol, cigarettes, http://english.alarabiya.net/en/ variety/2014/12/06/New-images-show-ISIS-burning-alcohol-cigarettes.html [access: 12.11. 2015]. 
convoys of shining Toyota pick-ups and tanks under black flags. It is only in the background, dimmed by desert sands, that we can see the cross-cutting interests of Saudi Arabia, Qatar, Iran, Russia and Turkey - where oil and money mix with political and religious ambitions (especially on the Sunni-Shia axis). On the actual battlefield the situation is no less complicated: ISIS fights Assad's army, but also the anti-Assad Syrian Free Army, while Assad aided by Putin bombs both of the above. At the same time, the Jihadis target the Kurds, whom the US reluctantly arm, to the chagrin of Turkey.

The expansion of the Caliphate takes parallel routes on the plane of symbolic communication - one could for instance mention the future-projected maps, or the printing of official passports with the logo of the Caliphate, etc.

A factor one cannot ignore in the context of symbolic communication comes in the form of the aforementioned brutal execution videos. It seems worth pointing out, however, that the recruitment propaganda is not exclusively based on violence. Importantly, various forms of rhetoric are utilised depending on whether the addressee is Muslim, or not, or whether they live in one of the Western countries, or in Chechenya, Russia or Africa. Thus, the videos made for the Caucasian recruits are mostly idyllic, for instance, depicting the cultivation of fruit orchards. It is therefore an incentive based on war-loot, such as soil, wife (or husband), house and welfare. Propaganda based on material gains was also attempted by Omar Hussain in Great Britain (he is better known under the media-nickname of the "Supermarket Jihadi”): “If this isn't enough, then Dawlah (Islamic State) also provides your family with the basic household items, such as a washing machine, fridge, cooker, carpets, mattresses and some other kitchen items [...]. Gas is also sold to the mujahidin (fighters) for less than half price and there is no water or electricity bills." 15

When it comes to the followers of Allah (and potential converts) in the West, the aesthetics directed at them is based upon the Hollywood pattern, i.e., dramatic shots and post-production. It is not hard to spot film sequences based on popular computer games (e.g., wide-angle shots from the subjective perspective of the shooter, where the barrel of the rifle serves as an extension of the camera-lens). This apparent reality-TV includes narratives in the native tongues of the addressees, which are meant to familiarise and efficiently radicalise attitudes. When it comes to the visual patterns, the

15 This boils down to the promises that the Islamic State would generously provide household equipment to the fighters' families, they would be able to purchase half-price fuel and would not be liable for any water or electricity bills. Source: http://www.mirror. co.uk/news/world-news/join-isis-fridge-bizarre-promise-6226404 [access:12.11.2015]. 


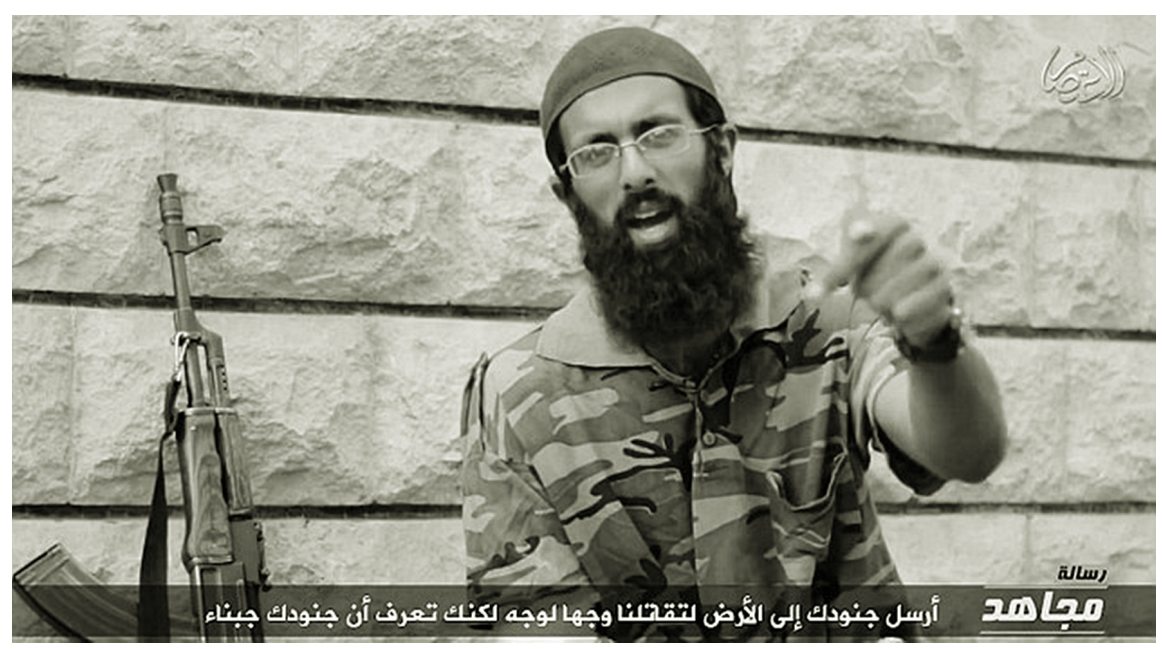

Source: http://www.dailymail.co.uk/news/article-2780253/Supermarket-jihadi-s-callarms-Former-Morrisons-worker-travelled-Syria-join-Islamic-State-challenges-DavidCameron-send-ground-troops-Iraq.html [access: 12.11.2015].

modern media serve as an indisputable ally (both those of the main-stream, and the social media), as their tabloid nature is often more prone to touch the emotional rather than rational notes. Thus, what comes as a result is an over-exposition of conflictual elements, which have a religious element in their background, which does in turn accelerate further tensions and phobias by way of a snowball effect. This completes the loop, as both the information media and the ISIS propagandists attempt to emulate the rhetorical forms characteristic of the cinema. In this way, the western world creates such negative celebrities as “Jihadi John.” In 2014 and 2015, he was performing executions on hostages (his victims included James Foley, Steve Sotloff and Kenji Goto), and during those executions he would give fiery speeches to the camera. In spite of his face being masked, he was soon identified as Mohammed Emwazi, a graduate of Westminster University. He gained his nickname thanks to his British accent as well as an unfortunate association with the leader of The Beatles by one of the former prisoners. According to British and American intelligence, Emwazi died during of one of the drone strikes on Raqqa (which was confirmed by Dabiq - a propaganda magazine of ISIS $\left.^{16}\right)$.

${ }^{16}$ More on the contents of the magazine: http://www.clarionproject.org/news/islamic-state-isis-isil-propaganda-magazine-dabiq\# [access: 12.11.2015]. 
On an iconic level one is compelled to make a comparison with the macabre spectacles of the western pop-culture - and especially with Quentin Tarantino's Inglorious Bastards (2009), where the assumption was that the viewers should bear no doubts as to the righteousness of the elaborate cruelties performed on the Nazis. The shots with the speeches of Jihadi John before executions replicate the cinematic poses of lieutenant Aldo Raine (Brad Pitt) with his indispensable knife.

Radicalisms crouching in the dark alleys of popular culture are also sometimes channelled into musically-focused subcultures, and thus there are the examples (far from infrequent) of recruiting German and French rappers into the ranks of IS. It seems worth noting the example of Sally Jones - an ex-singer of punk-rock from Chatham (Kent), who became a spouse of Junaid Hussain - a jihadi hacker. According to multiple sources, due to the bombing of Raqqa, Sally Jones is now a widow. ${ }^{17}$

Thus, ISIS propaganda falls on a specific soil in Europe, and is in a certain way convergent with such feelings of ethos which were characteristic of the recruitment drive of the Black Panthers among the Afro-American youth in the counter-culture times of the 1960s. It provides an opportunity of gangsterism, which seems ethically superior and more attractive as it is ideologically legitimised. In the case of joining the ranks of the Islamic State, such attitudes are reinforced by a substantial dose of religious motivation. For the converts, this generally consists in a cocktail of qur'anic quotations selected ad hoc and interpreted in the spirit of jihad. This is the reason why many of the authoritative imams disown the Islam of the ISIS brand - emphasising that it harms Muslims all over the world.

\section{Who is afraid of ISIS? Rationalisation of fear and anxiety}

At this point it seems worth considering the strategies of the rationalisation of the fears and anxieties spread by the radicalised Muslims. Fear based on islamophobia is commonly used by the governments of the threatened - as an element of the mobilisation of counter-propaganda. It allows for legitimi-

${ }^{17}$ T. Whitehead, Widow of British jihadist 'proud' he was killed by US, http://www. telegraph.co.uk/news/worldnews/islamic-state/11866046/Widow-of-British-jihadistproud-he-was-killed-by-US.html [access: 12.11.2015]. Cf. R. Spillett, Is 'Mrs Terror'back in Britain? Special Branch is on full alert after 45-year-old ISIS recruiter was 'seen in Birmingham with two jihadis, http://www.dailymail.co.uk/news/article-3197544/ISIS-recruiter-dubbed-Mrs-Terror-fled-Syria-Britain.html\#ixzz40oJ5Sg6j [access: 12.11.2015]. 
sing various military interventions: for instance, in the case of the elements of the George W. Bush doctrine of a pre-emptive attack, or the rhetoric of struggle against evil (essentially metaphysical, yet, directed by rational and pragmatic factors). A similar set of justifications involved the physical elimination of Osama bin Laden during Operation Geronimo in the time of Barack Obama's presidency. At the governmental level the actions involve implementing strategies of the effective management of fear and risk. In the face of the omnipresent fear-infection (by ISIS terrorism and national governments), what remains of higher interest are the diverse cultural immunological reactions. These more bottom-up tactics of familiarising fears are comprised of the following:

- conspiracy theories and falsifications - Internet users from all-over the world are analysing films and other ISIS propaganda materials searching for mystifications and cinematic tricks; among other things these involve the aforementioned executions of James Foley and of Japanese hostages, which served as a springboard for individual inquiries and investigations; the Internet was swarmed with arguments, based on analyses of individual frames from the execution clips, which attempted to demonstrate that they were shot in studio green-boxes. Thus, for instance, inconsistencies were found in the lightening of the hostage's faces as well as when it came to other editing and special effect errors; at the level of consequences there were suggestions that the productions were fabricated by the CIA (some of the shots showed supposed terrorists with what some Internet users would claim were tattoos characteristic of the US Army);

- humour - mostly spontaneous, often irreverent (e.g., the Charlie Hebdo satire-style), meant to diffuse tensions and anxieties: ridiculing ISIS iconography through countless memes: Japanese Internet-users created caricatures of executions stylised as manga-pictures, Israeli comedians created parodies of Jihadi films (following the style of their making, i.e., spoof reports from the shooting of the films, which would make fun of the problems terrorists had with proper pronunciation, the need for second takes, etc.), others still would compete to come up with Halloween costumes - in this case the appearance of Bin Laden was superseded by that of Jihadi John (which was made easy by the fact that one could easily find a ninja assassin costume in any supermarket, as it was a figure long familiarised by the pop-culture).

- entertainment - European conservatives are terrified by the record-breaking popularity of the Turkish soap-opera Magnificent Century; this 


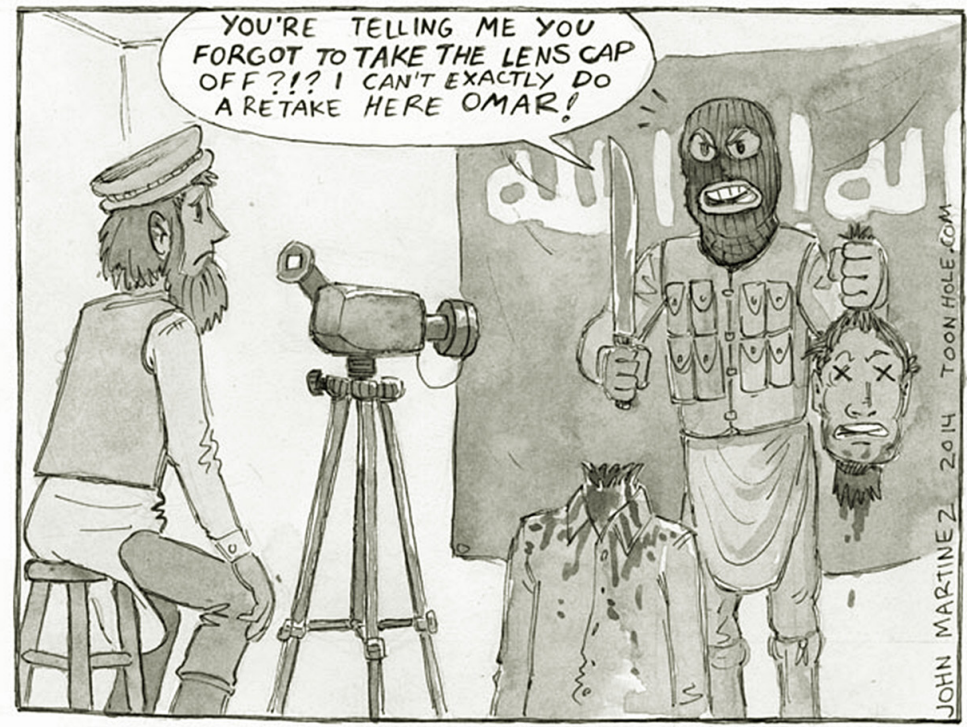

Source: http://toonhole.com/comic/al-qaeda-tapes/ [access: 12.11.2015].

historical TV-series tells the story of Suleiman the Great, where palace-intrigues and beheadings are justified by the logic of history, and the "black characters" in the Vatican are conspiring against Islam; entertainment in such a guise is perceived by right-wing circles as spearheading "unwanted" attitudes, as well as an excessive familiarisation and popularisation of Islam;

- gradual desensitising as a consequence of having seen a multiplicity of reports on ISIS cruelty; on the other hand, this is accompanied by an unhealthy fascination (entertainment, reality-TV horror); this constitutes a tabloid-voyeuristic appreciation of uncensored execution scenes on Internet websites; this is motivated by the desire to live through fear so far as it is controlled - and therefore the cultural mechanism is analysed multiple times, for instance, as the Kantian sublime (i.e., aesthetic excitement after a happily lived-through danger);

- compensatory aggression, as well as the so-called hating, where doubt seems warranted whether one should allow for such actions to be considered in the context of the rationalisation of fear, or is it an instance of an instinctive mechanism of a more primeval nature? Awareness of the risks of such a classification may allow us to assume that the violence against immigrants in Poland, for instance, are not only based on basic emotions and biological reflexes, but also on world-view elements. While the beatings remain sporadic incidents, the Internet demonstrates the terrifying magni- 
tude of the xenophobic hate-speech directed at Arabic immigrants; what is even worse, the web-haters seem unaware that their hate brings about the reverse result - it serves as an efficient fodder for the ISIS recruitment propaganda (and thus a perfect fertiliser for the radicalisation of Muslims settled in the West).

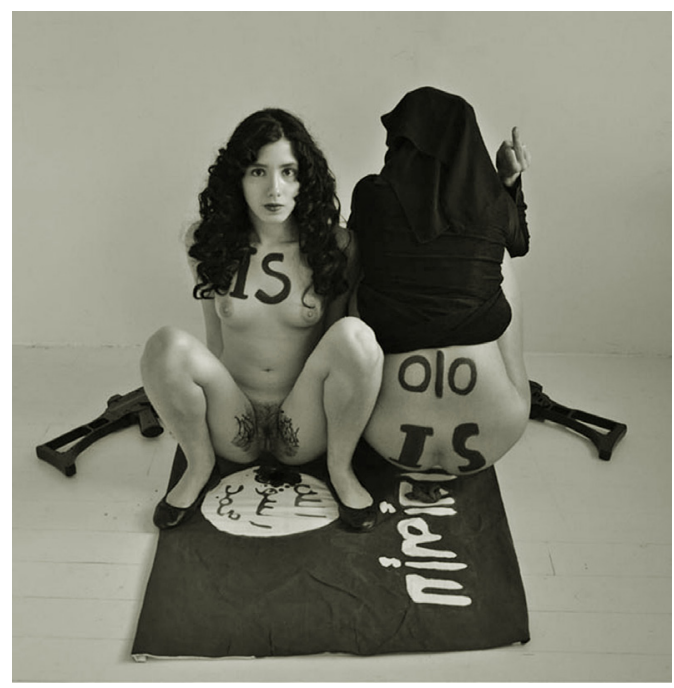

Source: http://hyperallergic.com/145768/feminist-activists-bleed-and-shit-on-islamicstate-flag-nsfw/ [access: 12.11.2015].

- discrediting - in August, 2014, an Egyptian feminist, Aliaa Magda Elmahdy, accompanied by a hijab-covered co-worker covered the ISIS flag with menstrual blood and faecal matter; pictures of this performance were published on her Facebook profile; by way of this cultural provocation she wanted to protest against the brutality and misogynistic ideology of the Islamic State; it seems worth mentioning that even lesser "infractions" were met with deadly violence in the West (one could mention the death of Theo van Gogh in 2004), and therefore the activist has now taken refuge in Sweden (although she sometimes cooperates with the Ukrainian Femen) ${ }^{18}$;

- distancing - \#NotInMyName, \#MakingAstand are examples of social campaigns run by Muslim women living in the west, in which a mass clearly disavow the ISIS brand of Islam; the presence of this action in the social

${ }^{18}$ N.Gillespie, Powerful: Egyptian Feminists Literally Shit, Bleed on ISIL Flag, https:// reason.com/blog/2014/08/25/powerful-egyptian-feminists-literally-sh [access: 12.11.2015]. 


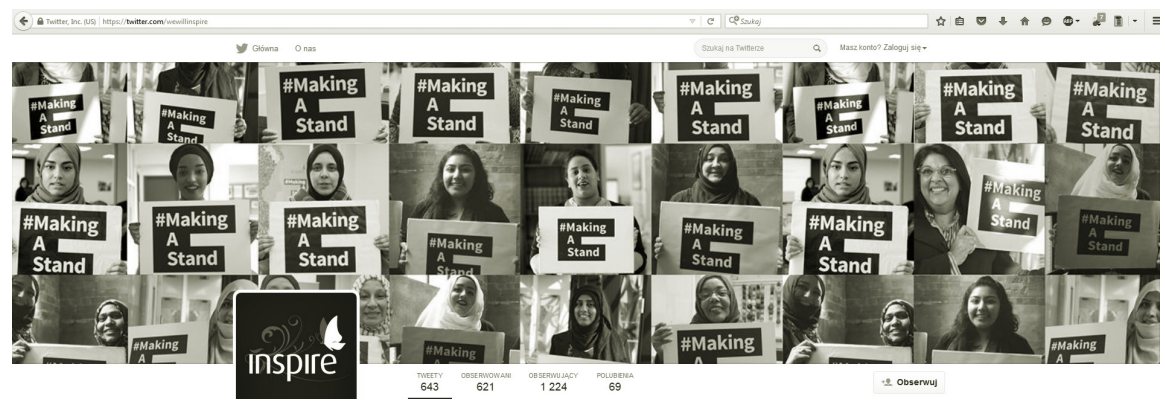

Source: twitter.com/wewillinspire [access: 12.11.2015].

media and on posters consists in bold portrait of women wearing hijabs while condemning extremism and terrorism ${ }^{19}$;

- art

Example 1: in 2015, the work Isis Threaten Sylvania of a London-based artist, Mimsy (daughter of a Syrian expelled from Israel to Lebanon) was removed from the exhibition Passion for Freedom in London's Mall Galleries. Afraid of potential riots, the police informed organisers that security for a six-day exposition would cost $£ 36,000$, which forced the work to be removed from the exposition. One could ask what caused such controversy? It turns out that the artist used a popular set of mascots to expose the tensions and threats stemming from today's terrorism - in the catalogue we could read: "Far away, in the land of Sylvania, rabbits, foxes, hedgehogs, mice and all woodland animals have overcome their differences to live in harmonious peace and tranquillity. Until Now MICE-IS, a fundamentalist Islamic terror group, are threatening to dominate Sylvania, and annihilate every species that does not submit to their hard-line version of sharia law...”20 Indeed, a number of light-box displays show idyllic scenes a moment before an imminent attack of armed and masked individuals. Mimsy has recreated the scenes moments ahead of the kidnapping of the schoolgirls by Boko Haram, while others present the scenes moments ahead the attack on tourists in Tunisia, etc. Jonathan Jones concluded that this mild phantasy of innocence seems

${ }^{19}$ N. Pathan, \#MakingAStand: British Muslim women launch anti-ISIS culture drive, http://english.alarabiya.net/en/life-style/art-and-culture/2014/09/24/-MakingAStand-British-Muslim-women-launch-anti-ISIS-culture-drive.html [access: 12.11.2015].

${ }^{20}$ Source: E. Weatherwax, Artwork showing Sylvanian Families terrorised by Isis banned from free speech exhibition, http://www.newenglishreview.org/blog_direct_link. cfm/blog_id/62392/Artwork-showing-Sylvanian-Families-terrorised-by-Isis-banned-from -free-speech-exhibition [access: 12.11.2015]. 


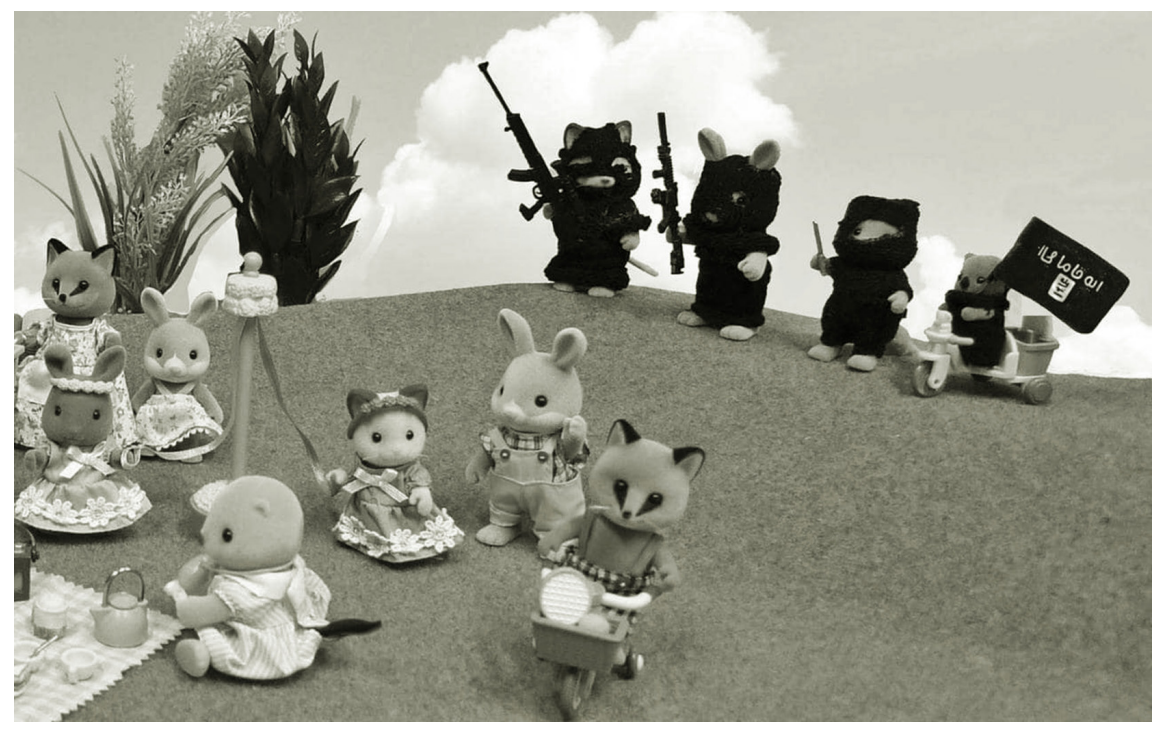

Source: http://www.telegraph.co.uk/art/what-to-see/sylvanian-families-isis-banned-freedom-expression/ [access: 12.11.2015].

almost to invite disaster, and so "If an artist can't show art on the grounds that it might provoke terror, the terrorists have plainly won"21;

Example 2: A British-Yemeni artist, Tasleem Mulhall, decided to demonstrate an installation Stoned at the same exhibition, which was meant to depict the social condition of Muslim women. it consists of a granite figure of a naked female (self-depiction) half-submerged in sand and surrounded by green blocks bearing the names of Arab states, as well as the inscription "Sharia law." The title of this work is purposefully polysemic - it may mean "killed by stoning," "set in stone” as well as "high on cannabis.” The author of this work is partly re-considering her own heritage - as a teenager she escaped from home to avoid a forced marriage. ${ }^{22}$ Currently, she is an art activist, and also works in many non-governmental organisations; she also is an independent photo-reporter.

${ }^{21}$ C. Armitstead, J. Jones, Artwork showing Sylvanian Families terrorised by Isis banned from free speech exhibition, http://www.theguardian.com/artanddesign/2015/sep/ 26/sylvanian-families-isis-freedom-of-expression-exhibition [access: 12.11.2015].

22 S. Troy, A Womans Right to Freedom, http://selfdiscoveryradio.com/2015/01/19/ p1504a-a-womans-right-to-freedom/ [access: 12.11.2015]. 


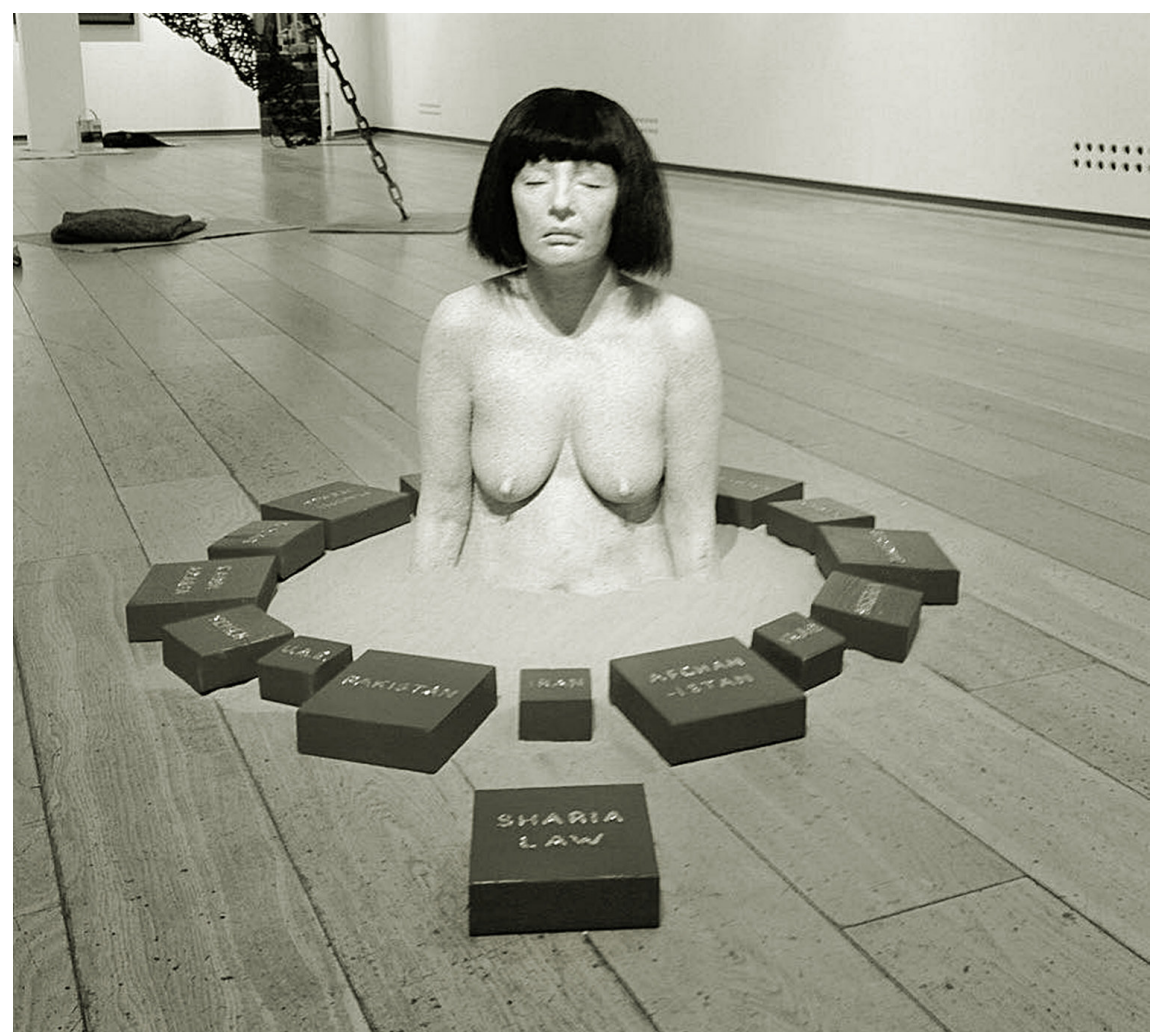

Source: https://selfdiscoveryradio.com/2015/01/19/p1504a-a-womans-right-to-freedom/ [access: 12.11.2015].

Example 3: Iranian artist Akeel Khreef made a highly expressive attempt to make fun of the Islamic State at an exhibition in the centre of Baghdad. Using the soles of used boots, he created a series of ensembles - caricatures of terrorists. It is important to mention that both in Iraq and almost all around the Middle East, showing someone the sole of one's shoe or throwing shoes at someone is considered highly disrespectful. As the artist put it: "I will not get them [the IS] out of my country with this work, but... I am certain they would be embarrassed by it"23;

${ }^{23}$ In Iraq it is considered extremely rude to call someone "waja al-kundara" - literally “face of the shoe.” Source: A. Karim, Iraqi artist gets creative with old shoes to mock ISIS, http://english.alarabiya.net/en/life-style/art-and-culture/2015/02/01/Iraqi-artist-gets-creative-with-old-shoes-to-mock-ISIS-.html [access: 12.11.2015]. 


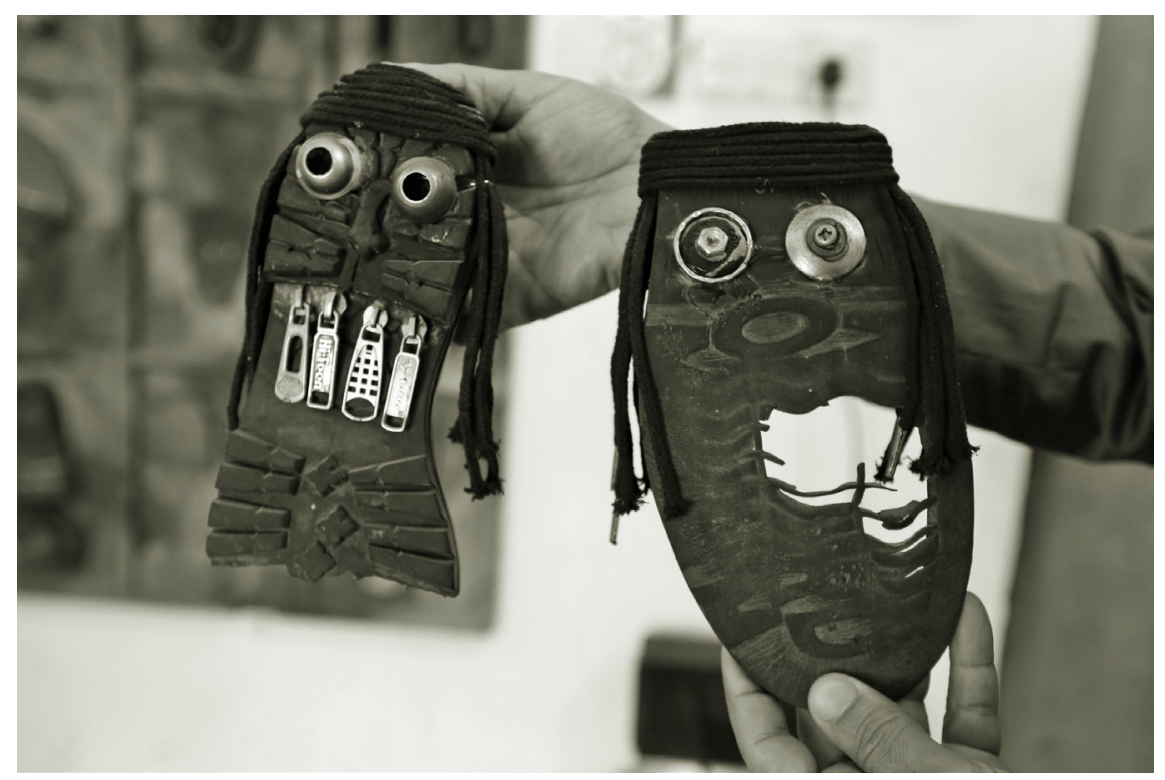

Source: https://www.yahoo.com/news/iraqi-artist-aims-kick-islamic-state-jihadists-052215902.html?ref=gs [access: 12.11.2015].

Example 4: As a part of the exhibition Civilized Society in Beirut (Ayyam Gallery) Kais Salman (Syrian) showed a picture entitled Brands (2014). ${ }^{24}$ It depicts a mundanely banal scene of some celebrity with a ring in their nose posing for the cameras, and there would not be anything special about it if not for a small detail: among many logos, such as Christian Dior, Dolce\&Gabbana, Gucci, etc, there unexpectedly lurks the flag of ISIS. This unassuming emphasis demonstrates the socio-cultural potential of the brand-logo, the seductiveness of symbols; on the one hand the desire, and on the other the ease of identifying with a known brand.

In summary of the section devoted to fear, in order to maintain symmetry, it seems worth asking in turn what are the ISIS fighters afraid of? In the propaganda posters they declare: Fear Allah Only! Yet, the repertoire of their fears and anxieties can be substantially broadened: the Quran provides suggestive visions of torment at various levels of hell (different for sinful Muslims, different for Christians and Jews, different still for the polythe-

${ }^{24}$ M. Alami, Arab artists depict violence in their paintings, http://www.al-monitor. com/pulse/originals/2015/02/arab-artists-painting-islamic-state-violence-syria-iraq.html [access: 12.11.2015]. 


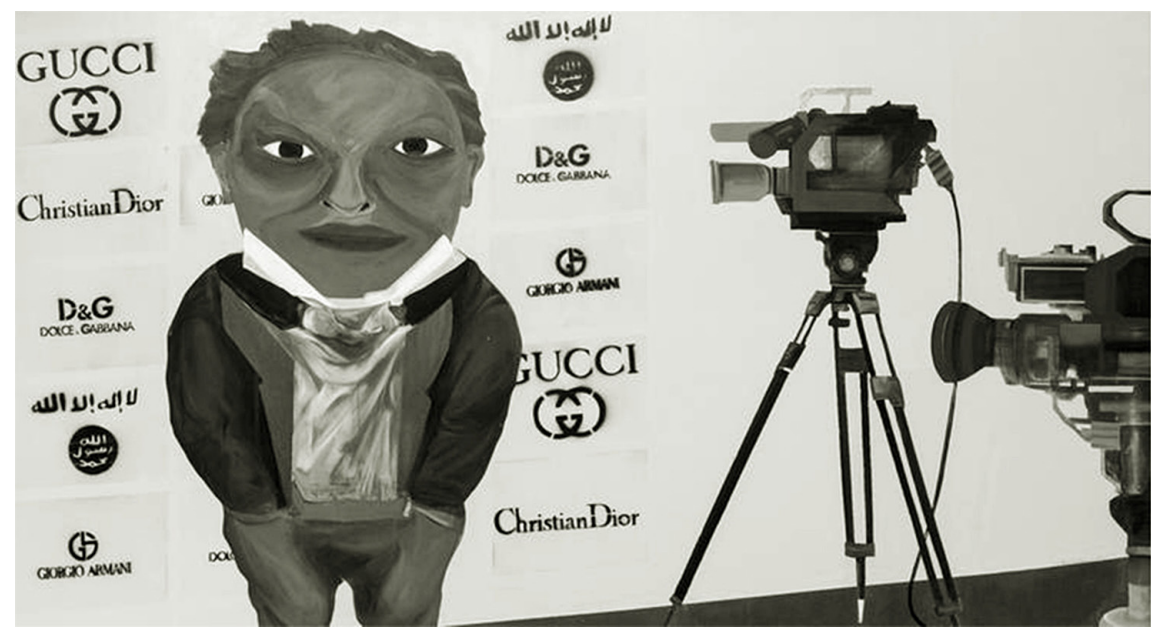

Source: http://www.al-monitor.com/pulse/originals/2015/02/arab-artists-painting-islamic-state-violence-syria-iraq.html [access: 12.11.2015].

ists). In spite of the declarative bravery and bravado of their conquests, the fighters are afraid of their enemies. This is one of the reasons behind the request that on the territories controlled by ISIS (especially in large cities, such as Mosul) all men have beards, so that the fighters may easily blend into the crowd if the need arises. In spite of their relatively good armament, the fighters are visibly afraid of attacks from the air, and especially those performed by drones. At the symbolic and cultural level, the former Jihadis have often articulated their fear of death at the hands of one of the Kurdish female fighters (highly frequent and increasingly better trained).

\section{Instead of a conclusion}

The kinds of ISIS rhetoric sketched above stretch between more or less refined acts of threatening and shocking. It has formed a broad repertoire of defensive reactions in Western culture. In spite of the always emphasised differences between the Islamic fundamentalists and the rest of the world, I would risk a thesis that we are still bound by certain common universals. Roughly, rational people are characterised by striving for cognitive consonance - therefore we exhibit a tendency to interpret events in line with our deeply held views. Cognitive consonance is permanently over-stretched - 


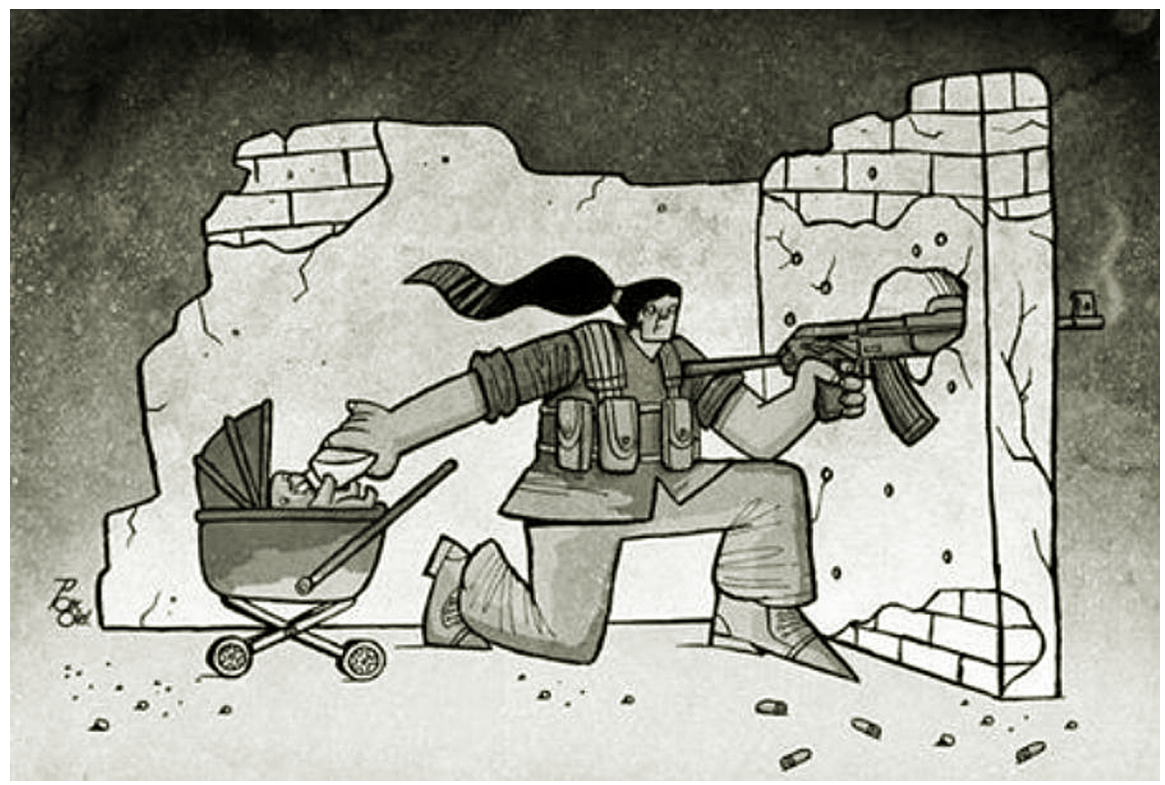

Source: https://325.nostate.net/2014/10/13/war-against-isisdaesh-kurdish-women-fighters-ypj-photos-kurdistan/ [access: 12.11.2015].

convictions are not assumed once and for all, but they are culturally shaped (for instance, by educationally, propagandistically or religiously shaped world-views). These processes also involve various critical, traumatic or shocking events (some would take it to be the attack on the WTC, others a caricature of Mohamed), which cause a cognitive dissonance.

When cognitive consonance and balance is stretched, this introduces a security threat, and, consequently, a special kind of tension, which requires unwinding. Aggression may be the answer, as in the case of the aggression against Afghanistan, or the attack on the editors of Charlie Hebdo. Aggression is neither the only form of reaction, nor a sufficient one; therefore, in order to assimilate a given event, we introduce such tactics as: distancing, minimising the event, repression, conspiracy theories, critical theories, etc. These actions are sometimes defensive, and on other occasions they may be of an offensive nature - as different individuals have different levels of tolerance for dissonance. The violence, symbolic or physical, present in these strategies serves as a factor unifying the world view (both at the individual and the collective level). It seems worth to recall the reverberations of Rene Girard's reflections, which construed collective violence as a culture-cre- 


\section{CRITICAL EVENT}

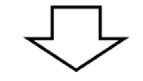

\section{COGNITIVE DISONANCE}

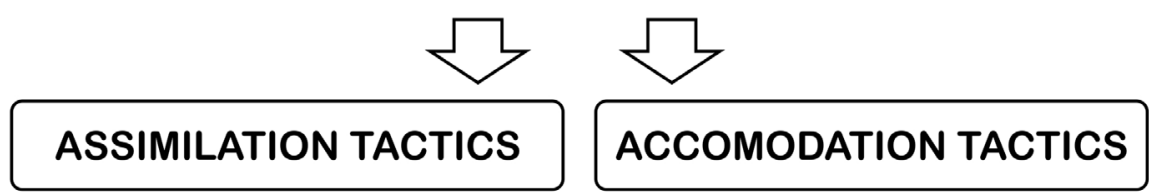

ating factor. This brings back the balance lost due to the aforementioned dissonance, but often at the cost of radicalisation and the petrification of the received system of convictions. This, in turn, leads to the sharpening of differences and a growing polarisation of the world. In order to balance out the assimilation-focused defensive tactics, it seems necessary to engage in a more difficult kind of thinking - one aimed at accommodation, i.e., not so much the reinforcing and strengthening of the foundations, as their reconstitution, allowing for the capacity to change. This seems to be the most pressing challenge for everyone - not only for the artistic culture and social activist. 